\author{
IZABEL S. RAMADAN \\ Higher Studies of Israel
}

\title{
MINORITY CULTURE, EDUCATION AND IDENTITY: THE CASE OF PALESTINIAN ARABS IN ISRAEL
}

\begin{abstract}
Ramadan Izabel S., Minority Culture, Education and Identity: The Case of Palestinian Arabs in Israel [Kultura, edukacja i tożsamość mniejszości - przypadek palestyńskich Arabów w Izraelu]. Studia Edukacyjne nr 43, 2017, Poznań 2017, pp. 335-349. Adam Mickiewicz University Press. ISSN 1233-6688. DOI: $10.14746 /$ se.2017.43.20
\end{abstract}

The purpose of this article is to address the links between minority culture, education and identity in the context of Palestinian Arabs in Israel (PAI). In an effort to demonstrate the unique socio-political status and cultural orientation of the PAI, the historical background of Palestinians in Israel is provided as well as a description of the educational system in Israel, with emphasis on Arab sector education. Against this background, I examine: (1) issues of education and identity among PAI and (2) the potential for identity conflict. Since the majority of teachers in the Arab sector are women, issues of gender relations are also discussed. The narrative methodology is recommended for further research on the way in which Palestinian Arab teachers, as potential agents of social change, relate to the broader cultural context in which they live and how identity issues are managed and expressed in the context of professional roles. The author of this article is a Palestinian Arab teacher in the Israeli educational system. This provides an opportunity for an in-depth analysis of the phenomena presented from an "insider" perspective

Key words: Palestinian Arabs in Israel, culture, identity, education, gender relations, narrative methodology

A system of education must help those growing up in a culture find an identity within that culture. Without it, they stumble in their effort after meaning.

Jerome Bruner

\section{Introduction and Background}

When the State of Israel was established in 1948, the indigenous Arab population remaining within the newly established country numbered 
156,000. ${ }^{1}$ Today, this indigenous ethnic minority numbers approximately 1.8 million, representing over twenty percent of the country's population of 8.3 million. Some 82 percent of the Arab population is Moslem, 9.4 percent Christian and 8.5 percent Druze. ${ }^{2}$

Palestinian Arabs in Israel(PAI) are a unique national minority of natives. ${ }^{3}$ We identify ourselves as Arabs who have inhabited an area referred to in various historical periods, including the British Mandate period, as Palestine. Yet, since 1948, we have been citizens of the State of Israel, which has been in a prolonged conflict with other members of our own people in neighboring Arab states. As Israeli sociologist Samy Smooha observes, PAI face a constant identity conflict in the problematic and delicate balance between citizenship (Israeli), nationality (Palestinian), ethnicity (Arab) and religion (Moslem, Christian and Druze). ${ }^{4}$

On the whole, the Arab sectorin Israel can be characterized as traditional, patriarchal and collectivist in cultural orientation. ${ }^{5}$ Emphasis tends to be placed on ascribed rather than on achieved statuses, on belonging to the extended family (hamula) and to the Arab people (Umma) and on binding duties to the collective. There remains a strict division of labor and role responsibilities between men and women, with priority placed on women's duties to home and family.

In contrast to the PAI culture, the dominant Israeli culture may be characterized as more individualistic in orientation. While the collective and extended family no doubt plays a central role among Israeli Jews as it does among Israeli Arabs, Jewish society places greater emphasis on individual

${ }^{1} \mathrm{~K}$. Arar, The State of Arab Education in Israel, Italian Journal of Sociology of Education, 2012, 1, p. 12.

2 Israel Central Bureau of Statistics, 2015

${ }^{3}$ H. Cohen, The Present-Absent: Refugees in Israel Since 1948, Van Leer Institute, Jerusalem 2000, 35.

${ }^{4}$ S. Smooha, The Model of Ethnic Democracy: Israel as a Jewish and Democratic State, Nation and Nationalism, 2002, 8(4), p. 475.

${ }^{5} \mathrm{~K}$. Abu Asbah, Education for Values in a Society in Crisis, Planning and Educational Counseling, 2012; K. Arar, A. Massry-Herzllah, A Motivation to Teach: The Case of Arab Teachers in Israel, Educational Studies, 2016; M. Dwairy, Personality, Culture and Arabic Society, Jerusalem 1997; M. Dwairy, Culturally sensitive education: Adapting Self-oriented Assertiveness Training to Collective Minorities, Journal of Social Issues, 2004, 60(2); M. Sharabi, The Relative Centrality of Life Domains Among Jews and Arabs in Israel: The Effect of Culture, Ethnicity and Demographic Variables, Community, Work and Family, 2014, 17(2); T. Shapira, Women in the Arab Educational System: Obstacles and Empowerment, Haifa 2009. 
achievement and freedom, personal identity and egalitarian gender relations. ${ }^{6}$

Prior to the establishment of the State of Israel, the indigenous Arab population, who were the majority of the population in Palestine, went to schools operated by the British Mandate government, while Jews attended educational institutions established by the Jewish community. This separation continued after 1948 in Arab localities within the borders of Israel. Today, almost all Arab students are taught by Arab teachers at separate public schools where the primary language of instruction is Arabic and part of the curriculum is specifically geared to the Arab culture. ${ }^{7}$

The Ministry of Education in Israel dictates the curriculum and pedagogic content for all public schools, Arab and Jewish alike. Government policy toward Arab education reflects a persistent perception of the PAI as a hostile minority whose national identity and expression of national consciousness presents a threat to the Jewish state and people. The general and specific goals for Arab education tend to "blur rather than enhance Arab identity"8 and pupils spend more hours learning about Jewish culture and values than their own. ${ }^{9}$ Moreover, the Western oriented education with its emphasis on independence and assertiveness is perceived in Arab society as a threat to Arab family unity and collectivism (327). This places Arab teachers in a difficult and at times untenable position.

The role of the Arab teacher is complex. To begin with, there are conflicting demands from the dominant culture, which teachers represent as employees of the state educational system, and the minority culture of the ethnic and religious communities to which they belong. Conflicting expectations appear to stem not only from questions of loyalty to the state and its official curriculum and from delegitimizing of the minority culture, but also from conflicting cultural norms for appropriate behavior among the two cultures: Arab and Jewish.

Israeli education is modeled after the Western philosophy of education where schools have traditionally been seen in positivist-functional terms as

${ }^{6}$ S. Sagy, E. Orr, D. Bar-On, E. Awad, Individualism and Collectivism in Two Conflicted Societies: Comparing Israeli Jewish and Palestinian Arab High School Students, Youth \& Society, 2001, 33(1); M. Sharabi, The Relative Centrality.

7 S. Swirski, N. Dagan-Bouzaglo, Discrimination, Inequality and Control: The Status Quo of Israeli Education, Tel Aviv 2009, p. 4.

8 I. Abu-Saad, The Work Values of Arab Teachers in Israel, Journal of Values and Beliefs, 2003, 24(1), p. 43.

${ }^{9}$ I. Makkawi, Role Conflict and the Dilemma of Palestinian Teachers in Israel, Comparative Education, 2002, 38(1), p. 39. 
catalysts for social change and progress. Schools promote deeply rooted Western values such as independence and self reliance, self efficacy, a belief in the power of scientific endeavors, and the ability of individuals to control or influence their own fate (Inkeles, Smith, 1974; Shils, 1980). One of the explicit goals of Western education is to enable the young person to separate from the family and to develop an independent self or identity. Yet Arab society in Israel, as Palestinian psychologist Marwan Dwairy (2004) maintains, is grounded in strict loyalty, obedience and duties to the collective and to the family, which take precedence over the individual. Assertiveness and independence, he notes, are frowned upon as rude, disrespectful and selfish and, therefore, as undermining the core values of the collective (328).

In addition to the clash of cultures within the school setting, there is the inevitable impact of the prolonged political conflict in the region. The official curriculum defined by the dominant Israeli culture has been aimed at promoting a collective national identity for the emerging Jewish state, which almost by definition excludes the non-Jewish population within its midst. In this sense, schools can be viewed not as neutral institutions that invest in human capital for the benefit of individuals and society but, rather, arenas for state control, the perpetuation of existing power relations, and the legitimizing of dominant cultural ideologies and value orientations. According to this view and its underlying conflict theory, education presents obstacles to change by hindering the development of minority groups. ${ }^{10}$

Given the unique socio-political context of Arab sector education in Israel and the centralized nature of the Israeli educational system, the question to be addressed in this article is: What are the links between minority culture, education and personal identity among Palestinian Arabs in Israel.

\section{Arab culture: A society in transition}

Arab society in Israel today can be characterized as a society in transition (Arar and Abu Asbah, 2010). ${ }^{11}$ Significant changes have taken place as a result of modernization and globalization. These changes are reflected in a rise in educational attainment, improvements in the standard of living, exposure to mass media and technology and the development of a political leadership

10 P. Freire, The Politics of Education: Culture, Power and Education, Westport, CT 1985; H.A. Giroux, Ideology, Culture and the Process of Schooling, New York 1981.

${ }^{11}$ R. Khamaisi, Transition from Ruralism to Urbanization: The Case of Arab Localities in Israel, Horizons in Geography,2012; D. Soen, Gender Equality? IJEMS, 2013, 6(2). 
that has replaced local, traditional authorities. However, as some have argued, changes have taken place primarily at the individual level and have not been translated into institutional and group resources. ${ }^{12}$

In Shalom Schwartz's terms, Arab society in Israel is an embedded culture where maintaining the status quo, harmony and the traditional social order rests on a high degree of group solidarity and where expression of individual feelings, aspirations and preferences are de-emphasized (1990, 1996). Embedded cultures rely on a strict hierarchy and an authoritarian system of ascribed social roles to enforce conformity and adherence to group norms. Social acceptance and belonging are motifs of paramount importance. The creation of clear boundaries between in-group and out-group, between "we" and "they" are a fundamental social fact in Arab society, as in other collective and authoritarian societies, which is aimed at reinforcing the sense of solidarity and collective belonging. ${ }^{13}$

Rassem Khamaisi (2012) traces the way in which the transition from a traditional to a modern society has altered the role of the hamulla as a predominant institution in Arab society in Israel. He claims that although its economic power has waned, the clan has accumulated power and resources in the community and, in this sense its traditional structure and influence are preserved (177). At the same time, Khamaisi notes, the exposure of young Arabs to hundreds of satellite and cable television stations, with 72 percent of Arab households connected to the Internet, has given rise to changes in cultural patterns of consumption, dress and leisure time activities. This has increased tensions between older and younger generations and between traditionalism and modernity and weakened the status of patriarchal elements (179).

Traditional role relations and division of labor between Arab men and women have not been significantly altered. According to Abu-Baker (2006), Arab men tend to cling to social and religious justifications for women's performance of traditional roles and responsibilities. Thus, although they stand to benefit from the employment of their wives, men are reluctant to make relevant adjustments the organization of family life. Often wives require family consent to work or study outside the home. The result for many women who continue their studies or who are employed has been to take on heavy dual responsibilities at home and on the job(45). One of the pro-

12 M. Al-Haj, Education, Empowerment and Control: The Case of Arabs in Israel, Albany 1995, p. 12.

${ }^{13}$ A. Mana et al., Perceptions of Collective Narratives and Identity Strategies: The Case of Palestinian Muslims and Christians in Israel, Mind Soc, 2012, 11, p. 166. 
fessions that is seen by male members of the family as legitimate for women is teaching. Thus often women pursue this option for employment, although they would have preferred other occupations over educational roles.

Thus, Arab women in Israel are doubly marginalized: First, as members of the Palestinian minority and, second, as inferior to men within Arab society. ${ }^{14}$ As women in a patriarchal society, we face oppression and exclusion from both the Jewish majority and the Arab patriarchy and social structure. This situation continues to impact upon women's participation in both Arab and Jewish societies respectively.

\section{Culture, conflict and education}

Conflicts in Arab education between traditional collectivist values, as described above, and Western individualist values are inevitable. A primary goal of modern, Western education in general and Israeli education in particular is to cultivate autonomy, skills and individual abilities so that students can live productive and fulfilling lives in society while they develop their own identities. Arab culture, as observed above, places greater relative emphasis on collective identity, on duties toward the family and on statuses that adhere to one's family background rather than personal achievements. These differences are likely to pose conflicts for teachers, particularly women, between national and cultural responsibilities and identities on the one hand and civic and professional responsibilities and identities on the other.

However, the conflict between collectivism and individualism is not the only conflict with which Arab teachers must cope. The prolonged IsraeliPalestinian conflict also creates continual dilemmas in education. One cannot begin to adequately understand this conflict and its impact on education without addressing the issue of historical narratives and their relationship to the national identity of Jews and Arabs alike. An "historical narrative" has been defined as how a given society understands its own identity and the events that created and gave rise to the sense of shared identity. ${ }^{15}$ In other words, according to Scham," It is the story that a nation tells itself," and thus "the sum total of the efforts of teachers, journalists, parents, other informal education and, perhaps lastly, the writings of professional historians" (59).

${ }^{14}$ D. Soen, Gender Equality?; T. Shapira, Women in the Arab Educational System.

${ }^{15}$ P. Scham, The Historical Narratives of Israelis and Palestinians and the Peacemaking Process, Israel Studies Forum, 2006, 21(2). 
The history of the Palestinian-Israeli conflict is the history of competition for sovereignty over the same geographic space. The national identities of both Jews and Arabs are intertwined with the phenomenon of exile from their land. Both the Zionist and the Palestinian national movements have as their goals the return to the land based on claims dating back thousands of years. The symmetry between the two people's claims leads, as Scham has observed, to a basic insecurity in historical legitimacy that both are seeking to remedy.

The historical narrative is a means to historical legitimacy and thus neither side in the conflict is eager to acknowledge the narrative of the other. As a result, Palestinian Arabs and Israeli Jews are locked in what Herb Kelman (2001) called "negative identity interdependence" (p. 187). Their life stories are inseparably interdependent and they are the main characters in one another's narratives, with the roles of heroes and villains reversed. They advance contradictory versions of the same events, dates and places. Thus, for example, Israel's Independence Day is a day of celebration for Jews, while for Arabs it is a day of mourning over the Nakba (the catastrophe) that befell them with the establishment of the State of Israel.

The public school in Israel, as elsewhere, reflects the "official" definition of the society concerning nationhood, citizenship and associated rights and obligations. As such, the Palestinian narrative is marginalized and delegitimized in the formal and hidden curricula. Israeli authorities use formal education and teachers themselves to repress national identity and awareness among Palestinian students. ${ }^{16}$ This puts Arab teachers like myself in the untenable position of having to convey and support a system of knowledge, beliefs and values that runs counter to their own.

Education in a pluralistic and multi-cultural society may be used to create a shared collective identity that encompasses the various groups while accepting their differences. This is the case when both majority and minority groups can identify with the national and ideological goals and the cultural symbols of the state (for example the flag, the national anthem, the language, etc.), as was true for the various waves of Jewish immigrants who were absorbed into Israeli society prior to and since the establishment of the state. ${ }^{17}$ The Arab population, however, did not immigrate to Israel but, rather, we are the offspring of an indigenous population upon which Jewish-Zionist

16 I. Makkawi, Role Conflict and the Dilemma, p. 40.

17 Y. Dahan, G. Levy, Multi-Cultural Education in the Zionist State, Studies in Philosophy and Education, 2000, 19, p. 423. 
ideology was imposed in 1948. In this context, the Arab school is not an institution for nation building but rather an arena for conflict.18

In The Culture of Education, Bruner (1996) asks whether schooling can be viewed as both the instrument of individual realization and at the same time a reproductive technique for maintaining or furthering culture. In an attempt to answer this question, he takes to task the architects of early educational programs like Head Start in America for their ethnocentric and narrowly interpreted notion of "cultural deprivation" as the absence of "American middle class, child-centered childrearing" that left too little room for particularistic cultural identities and traditions" (80-81).

Education, as Bruner claimed, is never neutral and never without social and economic consequences. No matter how it is conducted and in which culture, the consequences are instrumental for the individual and society. Knowledge, skills and ways of thinking and feeling that are promoted in schools have exchange value in the markets of society. In the broader sense, therefore, although claims are often made to the contrary, education is always political. One of the major tenets of cultural psychology is that the school can never be considered "culturally free standing." What and how it teaches is determined by the "situatedness" or the socio-political context in which it operates. ${ }^{19}$

\section{Identity issues among Palestinian Arabs in Israel}

Given the unique historic, social and cultural context of Palestinian Arabs in Israel, as described above, questions of personal and cultural identity have held considerable interest over the years for Arab and Jewish researchers alike. The major issue for research has been the extent to which Palestinian Arabs in Israel identify themselves as Israeli and to what extent they identify with the Palestinian nation in the region. The Six Day War in 1967 is considered a major turning point in this regard since it renewed contact between the PAI and Arabs in the West Bank and Gaza, ending twenty years of their effective isolation from the rest of the Arab world after 1948.20 This is seen as the beginning of a shift toward a greater sense of collective Palestinian identity.

18 I. Makkawi, Role Conflict and the Dilemma of Palestinian Teachers in Israel, Comparative Education, 2002, 38(1), p. 46.

19 J.S. Bruner, The Culture of Education, Cambridge MA, 1996, p. 28.

20 B. Schiff, Talking About Identity: Arab Students at the Hebrew University of Jerusalem, Ethos, 2002, 30(3), p. 274. 
Over the past thirty years, researchers have offered several different interpretations for how identity among Palestinian Arabs in Israel is managed and expressed. Some have seen increasing nationalism as a response to the decreasing influence of the clan (Peres and Yuval-Davis 1969). Others have argued that Arabs in Israel are conflicted between their national and civic identities, but unwilling to forgo their identities as Israelis. ${ }^{21}$ Both Smooha and Rouhana point to the preferred identity labels of "Palestinian Arabs in Israel" or "Israeli Palestinians". But, whereas Smooha (a Jewish Israeli) sees this as evidence of a divided loyalty (9-10), Rouhana (a Christian Arab) takes these labels as reflecting a form of distancing oneself from the emotional attachment to Israeli identity and voicing a separation between national sentiment and civic responsibility.

Research on the link between culture and identity has concerned itself, among other things, with psychosocial differences between minority and majority cultures in terms of feelings toward their cultural background and affiliation on the one hand and toward the dominant culture on the other. Cultural dimensions of self appear to be more salient for minority group individuals compared to majority group members. ${ }^{22}$ This is apparently related to the fact that membership in a lower status minority group has been found to negatively affect self esteem and increase identity threat. ${ }^{23}$ Lindsey (2004) argues that minority children in America face negative consequences of trying to reconcile the emphasis on tolerance toward others as a cultural value with their own lived experiences of exclusion. Thus, members of minority cultures are continually reminded of their backgrounds.

When individuals experience a threat to their sense of identity and self esteem, they employ various coping strategies to minimize the threat. ${ }^{24}$ For example, they may distance themselves from their cultural background and adopt characteristics of the dominant culture or they may focus on the merits of their minority in-group while devaluating aspects of the majority group. In his study of immigrant cultures, Berry (1990) defined four types of acculturation strategies using a variation of these two coordinates: Separation

${ }^{21}$ N. Rouhana, Accentuated Identities in Protracted Conflicts: The Collective Identity of Palestinian Citizens in Israel, Asian African Studies, 1993, p. 27; S. Smooha, The Model of Ethnic Democracy: Israel as a Jewish and Democratic State, Nation and Nationalism, 2002, 8(4).

22 J. Lindsey, Culture's Role in Teacher Identity: Prompting Teachers to Explore their Cultural Background, Action in Teacher Education: The Journal of the Association of Teacher Education, 2004, 1, p. 10.

${ }^{23}$ A. Mana et al., Perceptions of Collective Narratives and Identity Strategies: The Case of Palestinian Muslims and Christians in Israel, Mind Soc, 2012, 11, p. 168.

${ }^{24}$ Ibidem. 
from the majority culture and preservation of ties to minority group; Integration of the minority culture with aspects of the majority culture; Assimilation, with the relinquishment of one's own culture and the adoption of the dominant culture; and Marginality, referring to giving up one's own culture without adopting another.

Berry's model has been used to study acculturation tendencies among Arabs and Jews and among Moslem and Christian Arabs in Israel. ${ }^{25}$ On the whole, the empirical evidence supports the categories of the model and underscores the need to define a relevant out-group against which to see one's own in-group status and affiliation. The most prominent strategy of Arabs toward Jewish culture and relationships appears to be a form of integration.

Brian Schiff (2002) used narrative interviews with Arab and Israeli students to understand how Arab students, in particular, manage multiple identifications. He makes use of the expression "identity talk" to refer to a sense of collective selfhood in words (279). Cultural and social groups, he claims, provide the metaphorical currents or streams of thought that are the background for the formation of stories about the self. To a large extent, identity talk consists of accepting the stories of "narrative ancestors" as one's own stories. Narratives that are shared in one group may be challenged in another."Challenged" narratives play an important role in positioning one's in-group in relation to "other" (Lui and Hilton 2005, 1). Ayalon and Sagy (2011) relate to perceptions of such narratives in the context of the IsraeliPalestinian conflict. Their results reflect a deep difficulty on the part of each group to accept the other's narrative on the cognitive and emotional levels.

It is important to note that not all conflicts related to cultural identity in the Arab community are a direct function of the political conflict. Marwan Dwairy (2009), for example, describes the use of culturally sensitive methods and metaphor psychotherapy with Muslim Arab clients suffering from depression. The conflicts, he observes, are more often generational, between the client and the family, rather than internal, individual conflicts (201).

\section{Identity issues among Palestinian Arab teachers}

The preoccupation with issues of national identity has led researchers to ignore other identity issues such as those associated with occupation. There

${ }^{25}$ Ibidem; A. Ayalon, S. Sagy, Acculturation Attitudes and Perceptions of Collective Narratives: The Case of Israeli-Arab Youth, Youth Society, 2011, p. 43; N. Rouhana, Accentuated Identities in Protracted Conflicts. 
is, therefore, a gap in research on the professional identity of Arab teachers in Israel, particularly women. However, there is a sizeable body of research that looks at other issues, including cultural factors in Arab society that impact on the teaching role.

Arar and Massry-Herzllah (2016) looked at issues of teacher motivation. Based on their qualitative study, the authors concluded that many Arab women pursue a career in teaching not because they view it as a personal, national or socially significant mission, but because it is a reasonably secure and acceptable career for women in the Arab community that allows them to combine work and family management. This, they argue, undermines the sense of involvement with and affinity for the job and institutional affiliation (8).

Shapira (2009) examined the impact of social and cultural factors on the role, status and performance of Arab teachers in general and female teachers in particular. She cites the increasing level of education among women teachers as a central factor in processes of democratization in Arab schools and increasing teamwork among the staff. Based on responses to in-depth interviews, she describes the sample of 340 women on the whole as highly motivated, professional and driven by a sense of mission. Yet, at the same time their sense of empowerment and perceptions of their ability to affect change remain low. Shapira attributes this to the patriarchal structure of Arab schools and society as a whole. As she writes in her summary.

Keeping in mind that a high percentage of educated Arab women ultimately find their way to teaching, the meaning [of the research results] is that the very population with the potential to break the cycle of inferiority among women becomes part of patriarchal social structure... Within the existing structure, women teachers are subject to [male] social control and are not really free to develop a career in keeping with their skills and abilities (XII).

A particularly interesting finding in Shapira's research is that a significant number of women perceived themselves, nonetheless, as responsible for their own destiny (xi).In other words, rather than the traditional image of Arab women as dependent on others, there appears to be a shift toward a greater sense of individual autonomy.

Ronit Bogler (2005) researched occupational satisfaction of Jewish and Arab teachers inIsrael. She hypothesized that Arab teachers would experience greater frustration and dissatisfaction than their Jewish counterparts due to the fact that discrimination against Arabs in the workplace causes many to turn to teaching as a profession by default rather than personal choice. She assumed that over qualification would result in low satisfaction with the intrinsic rewards of the job in particular (22). Interestingly, Bogler found 
greater differences among male and female teachers than among Arabs and Jews on every aspect of satisfaction measured, with men being less satisfied than women (31).

The strongest predictor of satisfaction for both Arabs and Jews was a construct that Bogler refers to as "occupational perception" (19). Occupational perception was measured by a 28 item Likert scale designed to assess perceived status of the occupation, perceived autonomy, professional identity with the occupation and professional competence. To the extent that teachers perceived their jobs as high status and as providing opportunities for personal autonomy and development they expressed higher levels of satisfaction. Presumably, Arab men in the sample enjoyed greater autonomy and higher status on the job, which in turn gave them a greater sense of autonomy, competence and affinity with the institution.

An unusual study conducted by Nirit Reichel and Sara Arnon (2009) compared multi-cultural perceptions of the "good teacher" among four subgroups of Israelis defined on the basis of gender and ethnicity. In response to an open-ended question on qualities associated with the ideal teacher, ethnic origin proved to be more significant than gender in accounting for differences and similarities in perceptions among the 377 Israeli-born, adult respondents. A content analysis of the responses revealed three meta-categories of qualities attributed to the good teacher: (1) knowledge; (2) ethical values and (3) a good relationship with pupils.Arab Israelis uniformly pointed to ethical characteristics while Jews were more heterogeneous in their responses, with teacher-pupil relationships heading the list. The results support the notion that perceptions of qualities of a good teacher are clearly culturally dependent (59).

Despite the overall lack of attention to the role of Arab teachers in general and female teachers in particular in previous research, the general literature described above suggests that teacher attitudes, values and perceptions are strongly linked to culture, but also to gender.

\section{Conclusions and Recommendations}

As suggested in this article, educational systems can play a vital role in perpetuating or transforming cultural values and identities. Jerome Bruner wrote in The Culture of Education (1996), "A system of education must help those growing up in a culture find an identity within that culture; without it, they stumble in their effort after meaning" (42). In this regard, the role of 
Arab teachers within the educational system, their potential performance as agents of social change, and the cultural influences on their own personal and professional identities are subjects of vital interest. Nonetheless, there has been relatively little systematic study in these areas on the part of Palestinian Arab researchers in Israel.

One methodology that appears ideally suited to research on teachers and the impact of conflicting cultures, particularly cultures in conflict situations, on personal and professional identity is the narrative method. In sociology and anthropology, the narrative is often used to depict the character or life style of specific subgroups or subcultures as defined by gender, race, ethnicity, etc., particularly those who suffer from discrimination and marginality. In this sense, the narrative has been used to give voice to untold stories (See for example: J. Josselson, 1987; Gilligan, Rogers and Tolman 1991; Plummer 1995).

Narratives provide a window to the inner reality of individuals and their identities. But at the same time, many sociologists and psychologists would argue that they also give shape to the narrator's reality and identity (Gergen \& Gergen, 1986). ${ }^{26}$ The life stories told by individuals, particularly those stories that deal with inequality, frequently begin with unheard voices, but the footprints of the history, culture and social context in which the storytellers live their lives is inevitably and indelibly etched into the narrative. It is from this place that I believe Palestinian women in general and teachers in particular can make an important contribution to describing individual experiences within the broader cultural, social and political context in which we live our lives.

\section{BIBLIOGRAPHY}

Abu-Asbah K., Education for Values in a Society in Crisis, s.l.: Masser Institute of Research, Planning and Educational Counseling, 2012.

Abu-Baker K., Arab Society in Israel: Between exclusion and discrimination, Van Leer Institute, Jerusalemc2006.

Abu-Saad I., The Work Values of Arab Teachers in Israel, Journal of Values and Beliefs, 2003, 24(1).

Al-Haj M., Education, Empowerment and Control: The Case of Arabs in Israel, State University of New York, Albany 1995.

26 See for example: J.S. Bruner, The Culture of Education, Cambridge MA 1996; D.P. McAdams, Stories We Live By: Personal Myths and the Making of Self, New York 1993; D.E. Polkinghorne, Narrative Knowing and the Human Sciences, New York 1988. 
Arar K., The State of Arab Education in Israel, Italian Journal of Sociology of Education, $2012,1$.

Arar K., Massry-Herzllah A., A Motivation to Teach: The Case of Arab Teachers in Israel, Educational Studies, 2016.

Ayalon A., Sagy S., Acculturation Attitudes and Perceptions of Collective Narratives: The Case of Israeli-Arab Youth, Youth Society, 2011, 43.

Berry J.W., Psychology of Acculturation, Nebraska University, Lincoln NE 1990.

Bogler R., Satisfaction of Jewish and Arab Teachers in Israel, Journal of Social Psychology, 2005, 145(1).

Bruner J.S., The Culture of Education, Harvard University Press, Cambridge MA 1996.

Cohen H., The Present-Absent: Refugees in Israel Since 1948, Van Leer Institute, Jerusalem 2000.

Dahan Y., Levy G., Multi-Cultural Education in the Zionist State, Studies in Philosophy and Education, 2000, 19.

Dwairy M., Personality, Culture and Arabic Society, Al-Noor, Jerusalem 1997.

Dwairy M., Culturally sensitive education: Adapting Self-oriented Assertiveness Training to Collective Minorities, Journal of Social Issues, 2004, 60(2).

Freire P., The Politics of Education: Culture, Power and Education, Bergin and Garvey, Westport, CT 1985.

Gergen M.M. a. G.K.J., Narratives in Action, Narrative Inquiry, 2006, 16(1).

Giroux H.A., Ideology, Culture and the Process of Schooling, New York 1981.

Israel Central Bureau of Statistics, Satistical Yearbook, Jerusalem 2015.

Josselson R., Leiblich A., Interpretting Experience: The Narrative Study of Lives, Sage, Thousand Oaks 1995.

Kelman H.C., The Role of National Identity in Conflict Resolution: Experiences from IsraeliPalestinian problem Solving Workshops, Oxford Press, New York 2001.

Khamaisi R., Transition from Ruralism to Urbanization: The Case of Arab Localities in Israel, Horizons in Geography, 2012.

Kroeber A.L., Kluckhohn C., Culture: A Critical Review of Concepts and Definitions, Harvard University Press, Cambridge MA 1952.

Leiblich A., Tuval-Mashiach R., Zilber T., Narrative Research: Reading, Analysis and Interpretation, Sage, Thousand Oaks 1998.

Lindsey J., Culture's Role in Teacher Identity: Prompting Teachers to Explore their Cultural Background, Action in Teacher Education: The Journal of the Association of Teacher Education, 2004, 1.

Makkawi I., Role Conflict and the Dilemma of Palestinian Teachers in Israel, Comparative Education, 2002, 38(1).

Mana A., Sagy S., Srour A., Mjally-Knani S., Perceptions of Collective Narratives and Identity Strategies: The Case of Palestinian Muslims and Christians in Israel, Mind Soc, 2012, 11.

McAdams D.P., Stories We Live By: Personal Myths and the Making of Self, Morrow, New York 1993.

Polkinghorne D.E., Narrative Knowing and the Human Sciences, New York State University Press, New York 1988.

Reichel N., Arnon S., A Multicultural View of the Good Teacher in Israel, Teachers and Teaching, 2009, 15(1).

Rouhana N., Accentuated Identities in Protracted Conflicts: The Collective Identity of Palestinian Citizens in Israel, Asian African Studies, 1993, 27. 
Sagy S., Orr E., Bar-On D., Awad E., Individualism and Collectivism in Two Conflicted Societies: Comparing Israeli Jewish and Palestinian Arab High School Students, Youth \& Society, 2001, 33(1).

Scham P., The Historical Narratives of Israelis and Palestinians and the Peacemaking Process, Israel Studies Forum, 2006, 21(2).

Schiff B., Talking About Identity: Arab Students at the Hebrew University of Jerusalem, Ethos, 2002, 30(3).

Schwartz S.H., Individualism-Collectivism: Critique and Proposed Refinements, Journal of Cross-Cultural Psychology, 1990, 21(2).

Schwartz S.H. et al., Refining the Theory of Basic Individual Values, Journal of Personality and Social Psychology, 2012, 103(4).

Schwartz S.H., Ros M., Values in the West: A Theoretical and Empirical Challenge to the Individualism-Collectivism Cultural dimensions, World Psychology, 1996, 1.

Shapira T., Women in the Arab Educational System: Obstacles and Empowerment, University of Haifa, Haifa 2009.

Sharabi M., The Relative Centrality of Life Domains Among Jews and Arabs in Israel: The Effect of Culture, Ethnicity and Demographic Variables, Community, Work and Family, 2014, 17(2).

Smooha S., The Model of Ethnic Democracy: Israel as a Jewish and Democratic State, Nation and Nationalism, 2002, 8(4).

Soen D., Gender Equality? IJEMS, 2013, 6(2).

Suleiman R., Perceptions of the Minority's Collective Behavior and Voting Behavior: The Case of Palestinians in Israel, Journal of Social Psychology, 2002, 142(6).

Swirski S., Dagan-Bouzaglo N., Discrimination, Inequality and Control: The Status Quo of Israeli Education, Adva Center, Tel Aviv 2009. 